\title{
To Explore a New Way to Improve the Effectiveness of Ideological and Political Courses in Higher Vocational Colleges
}

\author{
Ting Liu
}

Jiangxi College of Applied Technology, Ganzhou, Jiangxi, China, 341000

3107000933@qq.com

\begin{abstract}
Under the guidance of Marxism, Mao Zedong thought, modern scientific development view and President Xi Jinping's new thought, we have explored the teaching methods and achievements of ideological and political courses in higher vocational colleges. By analyzing the effectiveness of ideological and political education, we will better guide students to study. Strengthen students' ideological education, guide students into the classroom, into the library, so that they can study tirelessly, and then in the society can have a skill to contribute to the society.
\end{abstract}

Keywords: Ideological and political education; learning; effectiveness

\section{探索提高高职院校思政课实效性的新路径}

刘婷

江西应用技术职业学院,赣州,江西,中国，341000

278835001@qq.com

\section{摘要}

在马克思主义，毛泽东思想，现代科学发展观以及习近平主席新思想的理论指导下，我们对高职院校 思政课的教学方式和成果进行了探究。通过对思政课教育的实效性进行分析, 我们将更好的引导学生 进行学习。加强学生的思想教育, 引导学生进课堂, 进图书馆, 让他们能够孜孜不倦地学习, 然后在 社会上能够有一技之长, 为社会做贡献。

关键词：思政教育；学习；实效性

\section{1. 前言}

由于社会的发展, 对学历的要求也越来越高。近几 年来高校纷纷扩招, 希望能够为群众们提供更好的教育, 提高人民群众的素质。除了大学之外, 高职院校也成为 了许多人们进修的选择。高职院校给学生提供了优良的 环境, 让学生掌握一些技术, 能他们够在社会上找到一 份好工作, 活出自我。同时, 学校也为同学们提供了思 政课, 不仅实让学生的技能得到锻炼, 更重要的是, 他 们的思想也得到了锤炼, 不仅会做事, 还要会做人。但 是, 是不是这些思政课都有效果呢, 我们将对思政课的 时效性进行探究分析。

\section{2. 高职院校思政课的现状分析}

表 1 高职院校思政课的现状分析

\begin{tabular}{|c|c|c|}
\hline $\begin{array}{c}\text { 高职院校不够重 } \\
\text { 视思政课教学 }\end{array}$ & $\begin{array}{c}\text { 大多数的大学生 } \\
\text { 不够重视思想政 } \\
\text { 治这门课程 }\end{array}$ & $\begin{array}{c}\text { 社会上存在着很多 } \\
\text { 的不良风气 }\end{array}$ \\
\hline
\end{tabular}




\begin{tabular}{|c|l|l|}
\hline $\begin{array}{c}\text { 高职院校往往只 } \\
\text { 重视专业课, 只 }\end{array}$ & 大多数的大学生 & \\
是把思政课当做 & 不够重视思想政 & 在社会上存在着 \\
需要完成的任 & 治这门课多程, 他不良风气 & 这对思政课的教学 \\
务, 学校对于思 & 普遍认为只有专 & 效果也产生了很大 \\
政课的监督管理 & 业课才是应当重 & 的负面影响, 随着 \\
也没有其他专业 & 视和认真学习的 & 物联网科技的不断 \\
课那么严格, 忽 & 目标, 是他们未来 & 发展。 \\
略了思政课的上 & 工作的重要依靠。 \\
课效果。 & & \\
\hline
\end{tabular}

根据不同渠道的调查信息, 我们发现, 现代高职院 校的思政课无论是在学生层面上还是在教师或学校方 面, 都面临着巨大的挑战。这些挑战大致表现在以下的 方面:

第一: 由于高职院校人数激增, 思政课只能被安排 在大班教学, 许多学生混水摸鱼, 教学的质量较差。

第二: 高职院校往往只重视专业课, 只是把思政课 当做需要完成的任务, 学校对于思政课的监督管理也没 有其他专业课那么严格, 忽略了思政课的上课效果。

第三: 教师并未引起重视, 在课堂上填鸭式教学, 不关心学生是否理解, 也因此, 学生就更加容易忽视这 一门学科。

第四: 大多数的大学生不够重视思想政治这门课程, 他们普遍认为只有专业课才是应当重视和认真学习的 目标, 是他们未来工作的重要依靠, 而学不学思政课对 他们的未来没什么大的用处, 不能给自己带来具体的经 济收益, 他们来上这门课程的原因也仅仅只是学校要求 以及学生部门点到, 就算他们来到教室上课, 由于是大 班教学, 人数过多, 所以他们都各自躲在人群之中玩手 机, 写其他课程的作业, 一节课下来除了老师提出叫人 解答问题几乎不曾抬头。

第五: 现在社会上存在着很多的不良风气，这对思 政课的教学效果也产生了很大的负面影响, 随着物联网 科技的不断发展, 人们通过在网上获取各种知识的渠道 越来越广, 获得的知识也愈发的杂乱, 而学生们对网络 上传播的信息是非的认知能力还有着很大的进步空间, 以至于他们都容易被网络上的不良信息给带偏, 对自己 上课所接收到的思想政治理论不够信任, 不愿意去接受 思政的教育, 对政治思想方面上各持己见, 这也使得老 师的教学难度大大增加。

从以上几个方面, 我们明白思政课的教学状况不容 乐观。我们需要改变, 需要重视起这一门学科。在思政 课上, 我们需要学习《毛泽东思想和中国特色社会主义 理论体系概论》这本书, 那我们应当怎样去学习它呢? 只是浅尝轩止是不行的, 我们必须要提高学习的实效性, 对教学模式进行创新, 让学生从学习中感受到乐趣。

\section{3. 高职院校思政课实效性的提高策略}

表 2 高职院校思政课实效性的提高策略

\begin{tabular}{|c|c|c|}
\hline $\begin{array}{c}\text { 设计新颖的教学 } \\
\text { 模式, 让学生 } \\
\text { “进课堂” }\end{array}$ & 布置课后作业 & $\begin{array}{c}\text { 向学生推荐优秀 } \\
\text { 书目 }\end{array}$ \\
\hline $\begin{array}{l}\text { 教师可以在课前 } \\
\text { 颁布一些主题, } \\
\text { 比如说 “邩小平 } \\
\text { 的伟大事迹”, } \\
\text { “改革开放的进 } \\
\text { 程” 等等。让学生 } \\
\text { 言之有物, 不至 } \\
\text { 于空洞无趣。当 } \\
\text { 课堂气氛调节起 } \\
\text { 来了, 学生必然 } \\
\text { 会自己积极地参 } \\
\text { 与到课堂中来, } \\
\text { 让课堂的效率变 } \\
\text { 高。老师也可以 } \\
\text { 结合实事与政治 } \\
\text { 主题来给学生分 } \\
\text { 享案例, 吸引同 } \\
\text { 学们的注意, 让 } \\
\text { 同学们一起讨 } \\
\text { 论,一起思考。除 } \\
\text { 此之外, 老师还 } \\
\text { 可以举办一些有 } \\
\text { 趣的活动, 比如 } \\
\text { 分小组拍摄思政 } \\
\text { 小故事, 然后让 } \\
\text { 同学上台拍摄, } \\
\text { 让同学评选出优 } \\
\text { 秀的小组, 老师 } \\
\text { 在对他们加分等 } \\
\text { 等。 }\end{array}$ & $\begin{array}{l}\text { 布置课后作业 } \\
\text { 其是与热点 } \\
\text { 政治问题相关 } \\
\text { 的作业, 比如台 } \\
\text { 湾的回归问题 } \\
\text { 等等。除了小作 } \\
\text { 业之外, 老师还 } \\
\text { 可以布置大作 } \\
\text { 业, 让同学们分 } \\
\text { 小组完成。这样 } \\
\text { 做的好处是, 能 } \\
\text { 够促进同学们 } \\
\text { 小组内部的合 } \\
\text { 作, 同时又能培 } \\
\text { 养同学们的竞 } \\
\text { 争意思, 让他们 } \\
\text { 小组与小组之 } \\
\text { 间竞争。并且, } \\
\text { 这样也不失为 } \\
\text { 一个将理论与 } \\
\text { 实践相结合的 } \\
\text { 好方法, 不仅仅 } \\
\text { 将学生的视野 } \\
\text { 局限在课本之 } \\
\text { 内, 还让他们去 } \\
\text { 查阅更多资料, } \\
\text { 去探索更加广 } \\
\text { 阔的世界。 }\end{array}$ & $\begin{array}{l}\text { 布置课后作业尤 } \\
\text { 其是与热点政治 } \\
\text { 问题 相关的作 } \\
\text { 业, 比如台湾的 } \\
\text { 回归问题等等。 } \\
\text { 除了 小作业之 } \\
\text { 外, 老师还可以 } \\
\text { 布置大作业, 让 } \\
\text { 同学们分小组完 } \\
\text { 成。这样做的好 } \\
\text { 处是, 能够促进 } \\
\text { 同学们小组内部 } \\
\text { 的合作, 同时又 } \\
\text { 能培养同学们的 } \\
\text { 竞争意思, 让他 } \\
\text { 们小组与小组之 } \\
\text { 间竞争。 }\end{array}$ \\
\hline
\end{tabular}

\section{1 设计新颖的教学模式, 让学生“进课堂”}

首先, “课堂 10 分钟 PPT 讲解”, 让学生上讲台讲 解 PPT 内容, 学生与老师的位置互换, 提高学生的注意 力, 并且让学生更加深入地了解这一个学科。教师可以 在课前颁布一些主题, 比如说 “邓小平的伟大事迹”, “改革开放的进程” 等等。让学生言之有物, 不至于空 洞无趣。当课堂气氛调节起来了, 学生必然会自己积极 地参与到课堂中来, 让课堂的效率变高。

其次, 老师可以结合实事与政治主题来给学生分享 案例, 吸引同学们的注意, 让同学们一起讨论, 一起思 考。除此之外, 老师还可以举办一些有趣的活动, 比如 分小组拍摄思政小故事, 然后让同学上台拍摄, 让同学 评选出优秀的小组, 老师在对他们加分等等。这样既让 
同学们有竞争和合作的意识, 又让同学们全神贯注的投 入到课堂中。

最后, 让学生的思考活动在老师的帮助下进行分层, 分段。比如可以说 讲学习的内容或者是教学的知识分 成众多的专题, 然后让学生进行分段分层学习, 养成独 立的思考。同时将课堂交给学生，让他们畅所欲言，同 时老师要进行相应的指导。

\section{2 让学生课下思考, 引领学生进“图书馆”}

\subsection{1 布置课后作业}

布置课后作业尤其是与热点政治问题相关的作业, 比如台湾的回归问题等等。除了小作业之外, 老师还可 以布置大作业, 让同学们分小组完成。这样做的好处是, 能够促进同学们小组内部的合作, 同时又能培养同学们 的竞争意思，让他们小组与小组之间竞争。并且，这样 也不失为一个将理论与实践相结合的好方法, 不仅仅将 学生的视野局限在课本之内, 还让他们去查阅更多资料, 去探索更加广阔的世界。只有理论没有实践是不行的, 两者相辅相成，缺一不可，也只有这两者结合，同学们 才能在社会上表现出更优秀的自己。

\subsection{2 向学生推荐优秀书目}

书是人类进步的阶梯, 老师可以给学生推荐优秀的 作品, 并且要求学生交读后感, 然后按完成的情况考査 登记成绩。为了完成任务, 学生会主动走进图书馆读书, 然后在不断地阅读之后，学生就会感受带阅读的鬼力。 在将来的日子里, 他们会在无人提醒的情况下自己走进 知识的殿堂, 去感受知识带来的乐趣。

\section{4. 积极展开实践教学、支持学生 “进社会”}

根据相关资料规定：“思想政治理论课的课程都要 加强实践，把实践教学与社会调查、公益活动、志愿服 务、专业课实习等结合起来”为了贯彻落实这样的规定， 教师应当将实践与教学相联系起来, 鼓励学生去实践, 并且给予学生相应的支持。让学生在实践中锻炼自己的 能力，在实践中不断地突破自己，突破极限。

实践的方式也有很多种, 学生可以去参与社会调查, 做公益活动, 去实习等等。在暑假期间, 老师可以给学 生布置 “暑期三下乡” 的活动, 让学生深入乡村, 深入 基层, 感受中国这些年的变化。如果学生下乡比较困难 的话, 老师也可以布置例如 “家乡的变化” “改革开放 之后的故乡” 等等的活动, 让学生自己主动去做社会, 去和人民群众打交道，做出满意的实践作品。在这样的 活动中, 同学们还能加深对课堂上知识的理解, 同时也 对中国的特色社会主义更加有信心。

鼓励学生去观察社会。在节假日中, 鼓励学生多多
观察社会上的不良现象，比如春节的鞭炮活动，清明的 一些祭祖活动。比如清明节, 中国历来有祭祖的习惯, 但是近几年来, 祭祖之风似乎过了一点。比如, 以前的 清明, 人们会自己动手剪纸钱献给祖先, 给祖先上香, 表达对他们的思念和尊敬。但是现在, 人们还会购买所 谓的 “别墅”，“小姐”，“百万冥币” 等等给祖先烧 去, 这样不文明的祭祖方式真是是祖先所希望的吗? 祭 祖的婳习也应当要有所改变才对。现在我们处于一个文 明道德的社会，我们就更加应该破除陃习，保护我们的 环境, 让社会主义科学发展观得到弘扬! 结语:

纵观全文, 我们明白思政课是非常重要的, 但许多 人还是会下意识的忽略它。因此, 我们要改进思政课的 教学模式, 引起高职学校领导和老师学生的重视, 并且 不仅要关注思政课的课堂教学,还要注重学生在课下的 实践。在大家努力下, 相信一定能够建设出具有实效性 的思政课堂!

\section{REFERENCES}

[1] Jiangbo. The Way to Enhance the Attraction Effectiveness of Ideological and Political Teaching in Colleges and Universities in the New Era [J]. Think tank age. 2020(01)

[2] Xialing. On the Way to Improve the Effectiveness of Ideological and Political Theory Course in Open Education [J]. Educational observation. 2019(35)

[3] Shi Yunli, Shenglei Ye. The Path of Teaching Innovation of Ideological and Political Theory in the New Era [J]. art and literature for the masses. 2019(15)

[4] Songyu. The Innovation Path of Ideological and Political Teaching in Colleges and Universities from the Perspective of Synergy [J]. Journal of Hefei Normal University. 2016(05)

[5] Lining. The Path of Improving the Teaching Effectiveness of Ideological and Political Courses in Colleges and Universities $[\mathrm{J}]$. Journal of Changchun Institute of Education. 2015(23)

[6] Zhongliang Zhu. The Way to Improve the Effectiveness of Ideological and Political Teaching in Colleges and Universities [J]. Education and Teaching Forum. 2015(03)

[7] Analysis on the Cooperative Mechanism of Practical Teaching in Ideological and Political Courses in Higher Vocational Colleges [A].] Peak. Proceedings of the Symposium on the Application and Analysis of Decision-making Forum — Management Decisions [C].] 2016 
[8] A Probe into the Practical Teaching of Ideological and Political Courses in Higher Vocational Colleges [A].] Shi Xinsong. Compilation of the Achievements of the 2019 Forum on Teaching Research and Teaching Writing Innovation (III) [ C].] 2019

[9] Make ideological and political lessons more approachable — Take the lesson of Strengthening Professional Ethics [A].] Zhang Hong. Chinese Vocational Association Award-winning Proceedings of the Year 2017(First and Second Prize) [ C].] 2018

[10] Promote double certification to improve management and teaching quality [A].] Zhang Chunfeng, Feng Hua. Higher Education Research 2006(Vol .1: Rector Forum Educational Reform) [ C].] 2006

[11] Changing Teaching Concepts Optimize Classroom Teaching and Improve Teaching Quality [A].] Xu Jiyun. - of Agricultural Education and Rural Reform and Development [C].] 2007

[12] Discussion on Improvement of Teaching Quality in Vocational Education [A].] Liu Luling. Proceedings of the 14th Shenyang Annual Conference on Science and Technology [C].] 2017

[13] An Analysis of Ways to Improve the Teaching Quality of Vocational Education [A].] Nie Yujiao. Proceedings of the Science and Technology Innovation Seminar of Heilongjiang Provincial Science and Technology Applied Innovation Commission in January 2016[ C].] 2016

[14] Some Experience of Teaching Innovation in Secondary Vocational Schools [A].] Zhou Hongxu. Compilation of Stage Achievements of the Eleventh Five-Year Plan (Chongqing Volume) [ C].] 2010

[15] Preparing lessons is the key to teaching [A].] Chen Qianjin. Excellent Essays of Chinese Private Educators [C].] 2006 